\author{
Sustinere \\ Journal of Environment and Sustainability \\ Volume 4 Number 2 (2020) 94-116 \\ Print ISSN: 2549-1245 Online ISSN: 2549-1253 \\ Website: https://sustinerejes.com E-mail: sustinere.jes@iain-surakarta.ac.id
}

\title{
RESEARCH PAPER \\ Modeling the role of perceived green value and consumer innovativeness in green products' consumption intention within the theory of planned behavior
}

\author{
Eunice Muraguri ${ }^{*}$, Sun Jin, Amadou Samake \\ Marketing Department, School of Business, University of International Business and Economics, Beijing - \\ People's Republic of China \\ Article history: \\ Received 19 April 2020 | Accepted 08 August 2020| Available online 26 August 2020
}

\begin{abstract}
Sustainable consumption is on the rise, however scarce literature exists to explain the consumers' perceived green value of green home apparel in the Chinese context. This study while applying the Theory of Planned Behavior (TPB) explores consumers' intention to consume green products guided by Perceived Green Value (PGV) dimensions of utilitarian value, environmental value and hedonic value through a study of electric home appliances in China. The key findings established from a survey of 426 students in Beijing - China reveal a positive significant relationship between the three green value dimensions and the TPB factors' of attitude, subjective norms and perceived behavioral control. The relationship was however strongest between the three dimensions and attitude. Further, the relationship between TPB factors and intention to consume green products was significantly positive. In addition, consumer innovativeness positively moderated the relationship between the three PGV dimensions and attitude. The discussion and conclusion outlines the theoretical implications and the value dimensions for marketing practitioners and policy makers to focus on in order to enjoy long term business sustained success. The scholars acknowledge the study limitations and offer research directions for future studies.
\end{abstract}

Keywords: Perceived green value, environmental value, utilitarian value, hedonic value, consumer innovativeness, consumption intention.

\section{Introduction}

In the recent past, there have been a significant increased awareness of different environmental problems and it has become a global concern to reduce negative impact on the environment (Sandu, 2014). Environment deterioration is currently on the public attention which is majorly as a result of overconsumption of natural resources. Different measures have been established by firms in an attempt to curb the situation by including environmental protection measures into their operations with the main objective of customer satisfaction, 
consumer rights protection and portraying themselves as socially responsible (Mei et al., 2012). Practitioners and scholars have come to appreciate the important role of green practices by various stakeholders such as the local government and firms in the cause and effect of climatic changes. As noted by Erridge and Hennigan (2012) and Melissen and Reinders (2012) however, most studies into green practices concentrate at the organizational, national or international level but barely at the level of individual end consumer. It is important to note that environmental protection does not only depend on the efforts put forward by regulatory authorities but also on the choices that consumers make daily in regards to what they consume, their attitude towards environmental protection as well as what they are willing to forego (Benedek et al., 2013).

China as one of the largest emerging economies is faced by a variety of environmental related pressures such as extremely high domestic pollution and the external pressures to jointly act and curb global warming (Liu et al., 2012). However as noted by Head (1996) though there are widespread campaigns on green movement in companies, positive outcomes as a result of embracing environmental measures by consumers in China is taking long to be felt. In comparison with countries in the West, China has been slow in embracing environmental sustainability and management (Chan \& Lau, 2000). The Chinese household appliances market is said to have experienced a tremendous growth over the past few years and is expected to continue growing. The growth is attributed to urbanization whereby in the years between 2009 and 2013 annual sales of residential properties grew by 37.3\% from 8 million to 11 million ("Household appliances in China 2015," 2015). Major appliances accounted for included refrigerators, washing machines and ovens. The report further stated that the total revenues for the Chinese household appliances market in 2014 was USD 109.6bn representing a compound growth rate of $13.2 \%$ between 2010 and 2014 . The market was projected to reach a value of USD $178.2 \mathrm{bn}$, marking an increase of $62.6 \%$ by 2019. In line with studies by Young et al. (2010) this study will focus on the consumers' intention to buy green household electrical appliances such as washing machines and fridges, household electrical entertainment appliances such as CD players and televisions, small household appliances such as juice blenders, bread makers and electric kettles, computers and laptops.

In the past few years, product sustainability claims and their associated influence on consumers' decision making have been given an upper hand in several studies (Jaffee \& Howard, 2010; Luchs et al., 2012). Product sustainability couples up as consumer pro-environmental behavior which is also interchangeably referred to as green purchasing, ecological behavior or sustainable consumer behavior. It is both an extrinsic and intrinsic well thought out action by an individual to take care of the environment for future generations (Papaoikonomou et al., 2011). Most of the researches have tried to establish the tradeoffs facing consumers when making sustainable decisions (Prothero et al., 2011; Vitell, 2003). The studies reveals that, although consumers note that they consider sustainability factors when making a purchase and would be willing to even pay an extra amount to acquire sustainable goods, this does not always translate into real purchases (Luchs et al., 2012; Luchs \& Kumar, 2017). Nielsen (2014) carried out an online global retail study and observed that though $51 \%$ of the consumers indicated that they would be willing to pay a premium for sustainable products, their intentions did not match their actual buying decisions (Kleanthous \& Peck, 2013). Theorists purport that environmental consciousness is not the only factor that even the green minded consumers consider when purchasing green products, but rather, the decision is as a result of a detailed comparison 
between what is gained in terms of value and what is sacrificed in terms of costs (Papista \& Krystallis, 2013). Customers' perceived value is a construct that is referred to as one of the cornerstones in the discipline of marketing (Mustak, 2014). The intention to behave in an ecofriendly way, in this case purchase green products, have been regarded as complex and still under debate as it involves both pro-environmental and self-interest motivations (Miller et al., 2015). Rational consumers when making a purchase decision try to achieve the best value possible through an evaluation of what is gained versus what is given up in return. This study models utilitarian value, environmental value and hedonic value as three dimensions of perceived green value (PGV) and attempts to establish: (a) the effect of the three PGV dimensions on attitude, subjective norms and perceived behavioral control (b) the effect of attitude, subjective norms and attitude on intention to consume green products and (c) the mediating role of consumer innovativeness on the relationship between the three PGV dimensions and attitude.

\section{Literature review}

\subsection{Theoretical foundations: Theory of Planned Behavior (TPB)}

TPB is termed as one of the most powerful and influential structured framework that predicts and explains human behavior (Ajzen, 1991). The three constructs of Theory of Planned Behavior (TPB) that model human behavioral intentions are attitude, subjective norms and perceived behavioral control. TPB depicts that an individual's intention to perform a behavior and his perceived control over the behavior predicts his performance of a behavior. Consequently, attitude towards a behavior, subjective norms (SN) and perceived behavioral control (PBC) can predict someone's intentions. Attitudes toward a behavior refer to a wholesome evaluation of positive or negative consequences of performing a behavior (Roos \& Hahn, 2019). Belk (2014) concluded that consumers are most likely to have positive attitude towards ethical consumption because the benefits derived exceed the cost incurred. Social norms are defined as the perceived or social pressures and expectations arising from a given group of people, individuals or the society (Fishbein \& Ajzen, 1975; Olsen, 2004).

Subjective norms in relation to people and public figures that a consumer looks up to for example family members, friends and role models shape up a consumer's consumption intention and will be considered in this study. Questions will be geared towards establishing consumers' perception towards intention to consume green products while alone and while in company of persons that shape their consumption decision making. PBC as a predictor of behavior denotes the perception of an individual of the perceived difficulty or ease of executing a behavior (Ajzen, 1991). Control beliefs refer to the third salient group of beliefs which result in perceived behavioral control (Pawlak \& Malinauskas, 2008). They denote the difficulties that consumers perceive which are associated with behavioral performance. Among the most significant factors that influence consumers' green products purchase are availability, accessibility, cost, and related information. This study sought to establish the consumption intention of green products while guided by the TPB. Perceived green value of utilitarian, environmental and hedonic value in relation to the three TPB factors was established. PGV dimensions were regarded fit to model this relationship since as noted by Sheth et al. (1991) and Zeithaml (1988) the concept of consumer perceived value has widely been studied and regarded as a major predictor of consumer decision making behavior. Consumer perceived value is defined as an assessment of the overall utility of a product based on the perception of what the consumer receives versus 
what is given (Zeithaml, 1988). Research approach in the recent past conceptualizing perceived value as a multi-dimensional construct with various value dimensions is also gaining acceptance.

Shaw and Shiu (2002) introduced the first conceptual model that structured TPB to predict buying decision making process by ethical consumers. The study was carried out in the context of fair trade food consumption where ethical obligation and ethical identity were noted as dominant determinant of ethical consumption. Subjective norms and perceived behavioral control constructs however had insignificant influence on consumption intention (Shaw \& Shiu, 2002). Another study on ethical apparel consumption indicated a significant relationship between attitude and social responsibility and the intention to buy ethical apparel while perceived behavioral control had no significant impact (Koh \& Noh, 2009). To further understand the role of attitude, SN and PBC on the intentions to consume green products, Huh (2011) extended Shaw and Shiu's (2002) model of TPB. In the context of green products such as pro-environmental agricultural produce, clothing, fair trade coffee and chocolate, findings established a positive relationship between attitude and ethical obligation, consumer efficiency, ethical identity and altruism. This study aims to extend the study on green products consumption while applying TPB in the context of electric home appliances.

\subsection{Development of hypotheses}

\subsubsection{Green products' utilitarian value}

Utilitarian attributes of a product are the attributes that relate to the performance of a product. They contribute to the efficiency and functionality of a product while improving the consumers' perception of safety, quality and performance (Okada, 2005). Attributes of a product refers to the particular dimensions of a product that are used when evaluating the choice alternatives. These include quality, style, brand and price (Hsu \& Burns, 2002). Utilitarian value of green products include the energy efficiency of products, incorporation of recycled materials in production of a product, environmental friendly packaging materials and use of organic ingredients. Luchs et al. (2012) notes that though several studies have examined products with green attributes, empirically they have not investigated perceptions of utilitarian value associated with green products.

According to Papista and Krystallis (2013) consumers may not directly receive the immediate benefit from buying a green product but there are high chances that the consumer have an initial concern about the long term implications of the product. A large number of consumers have the notion that green products purchase and consumption offers more utilitarian advantage than traditional alternatives (Hartmann \& Apaolaza-Ibáñez, 2012). Use of front-loading washing machines for instance is considered better than the traditional toploading machines since it is more-gentler on clothes and cleans better. Pro-environmental behavior revolves around the context of selection, buying, consumption and disposal. To this effect, this study will dwell on the intention to select, buy and consume green products. The initial stage of buying will be guided by the utilitarian green aspects of whether the product is a remanufactured product, is made out of recycled materials and if the packaging is satisfactorily done. Firstly, remanufacturing in this study will refer to the direct method of reuse whereby returned products are converted into conditions of 'like new' for resale. This entails replacing worn or broken components, repairing defects, disassembling and repackaging for sale. Arndt (2005) argued that remanufacturing can be both more profitable and faster-growing than in 
some cases, new manufacturing. Remanufacturing is advocated for since apart from reducing and lessening the depletion of virgin raw materials it also notably require less overall energy than new manufacturing.

Packaging falls under waste management at the source and is considered a pre-recycling strategy. The study will focus on over-packaging of products and recyclability of the main product after use as well as its packaging materials. Over-packaging refers to a primary or a secondary packaging that is inappropriately large or bigger than the size of the product it contains (Monnot \& Reniou, 2012). Schwepker and Cornwell (1991) noted that packaging over the decades has been acknowledged as the main reason for the sudden increase of solid waste. They further noted that over-packaging is responsible for unnecessary consumption of resources and when a consumer chooses an otherwise unnecessarily over packaged product it leads to generation of more household waste and pollution. This study therefore hypothesizes:

H1: Green products' utilitarian value is positively associated with consumers' (a) attitudes (b) subjective norms and (c) perceived behavioral control.

\subsubsection{Environmental value}

The initial general concern for the environment is mostly attributed to the USA in the 1960s and the economic effect arising thereof has steadily increased over the years (Buchholz, 1993; Elkins \& Callaghan, 1978). Consumers' environmental concerns span from environmental awareness which is a broad term that refers to understanding the environment and obtaining necessary skills and values to solve problems related to the environment. It is the ability of a consumer to understand and differentiate the current human activities, the quality of environment and the drive that an individual has in participating in environmental activities (Umuhire \& Fang, 2016).

Zimmer et al. (1994) stated that environmental concern is a general concept that denotes issues and feelings related to various green issues. These issues include; being concerned about waste, wildlife, biosphere, health, popular issues, environmental technology and energy awareness. According to Bamberg (2003) environmental concern is an aggregate of perceptions related to environment which are knowledge, emotions, attitudes, behaviors and values. Environmental concerns therefore may arise as a result of certain specific attitude related to known facts or as a result of general attitude or value perceived. Environmental awareness is considered as an important necessity in environment protection (Du et al., 2018). It is further considered as a prerequisite step that leads to promotion of responsible citizenship behavior as well as a powerful tool in promotion of environmental policy (Sengupta et al., 2010).

According to Serafimova (2016) establishing how much a society know about the environment, their feelings towards it and the actions they take is necessary in establishing the sustainability of that society. When consumers purchase products that are environmentally friendly, it is generally believed that this contributes significantly to improvement of the quality of environment. Under perceived green value of environmental concern, this study will concentrate in areas of use of green eco-labels, waste management and pollution issues. Environmental concern is termed as one of the major consideration in decision making process by consumers when purchasing electric and home appliances. Energy efficiency is the main drive whereby energy efficiency standards and eco- labels for electric and household appliances are 
the most prevalent and effective strategy for energy saving and creation of awareness to consumers about the environmental impact of the product they intend to buy (Jørgensen \& Moen, 2015). However on the same note, the results of Consumption report by EU in 2009 indicated that only $10 \%$ of consumers by then recognized the ecological or green energy labels quoted on the appliances in supermarkets in Europe (Eurostat, 2009).

Waste management at the individual consumer level as a concern in environmental consideration refers to post purchases waste management. Of great concern is the manner in which consumers manage or deal with waste after the successful use of a product. As noted by Elgaaïed-Gambier (2016) most of empirical research on waste management at the consumer level concentrate at the recycle level but not at the source of the waste. Pollution is another gray area and according to a report by UNEP (2017) pollution is in the modern world today persistent and pervasive. While significant economic growth have been achieved in the past few decades, large amounts of pollution have been released which have a significant negative effect on ecosystems, human health and the functioning of some major earth system processes such as the climate. The report appreciates major strides that have been achieved in fight against pollution but goes further to point that an approximate 19 million premature deaths are projected to occur each year as a result of the manner in which societies in pursuit of production and consumption consume natural resources and its impact on the environment. The study therefore hypothesizes that:

H2: Environmental value is positively associated with consumers' (a) attitudes (b) subjective norms and (c) perceived behavioral control.

\subsubsection{Hedonic value}

Consumers' perceived value is considered as one of the most important aspect of retail differentiation since it categorizes consumers' wants and beliefs, their perceived expectations after purchase and their actual experience during consumption of the acquired products (Kazakeviciute \& Banyte, 2012). Hedonic value is associated with a consumer's desire for knowledge which can either be as a result of intellectual curiosity or in search of novelty (Kang \& Park-poaps, 2010). A hedonic shopping experience is manifested by the ability to offer a consumer pleasure and satisfaction for example through stimulation of joy, fantasies and entertainment. Thus, a hedonic shopping aspect is often characterized by joy that is manifested while using the product or through new experiences and pleasures experienced when shopping (Ballantine et al., 2010).

While seeking for knowledge, otherwise referred to as exploration, the process accords a consumer hedonic value when they enjoy the excitement of the product's offering or they enjoy the information search (Chandon et al., 2000). Consumers tend to choose and seek for alternatives when they are tired or get bored of the existing products, when they are yearning to gain more knowledge and have a taste of new experiences. Substitute seeking motives and novelty have been identified as major factors that can be exploited in encouraging brand and product search, carrying out trials and observing switching behaviors (Sheth et al., 1991). Hedonic value therefore can be an important element for consumer considering browsing for new experiences in green consumption. Based on this, the study hypothesizes that: 
H3: Hedonic value is positively associated with consumers' (a) attitudes (b) subjective norms and (c) perceived behavioral control.

\subsubsection{TPB constructs and intention to consume green products}

TPB was found fit to predict consumers' intention to consume green products in this study because of a number of reasons. First, the theory's three constructs explain the primary determinants of behavioral performance which are relevant in green products consumption. Attitude most especially captures consumers' evaluation of perceived benefit and cost implications of green products consumption (Roos \& Hahn, 2019). Secondly TPB has been widely used to explain other diverse consumer behaviors such as health related services such as in consumption of ethical products (Oh \& Yoon, 2014) in the food sector and dry food consumption (Olsen, 2004; Siddique, 2012) purchase of environmentally friendly products (Sejwacz et al., 1980) attitudes towards genetically modified products consumption (Schepers \& Wetzels, 2007) among others. Third, TPB advocates for inclusion and testing of additional variables (Icek Ajzen, 1991). The theory is therefore suitable in examining the influence of utilitarian value, environmental value and hedonic value and comprehensively establishes the role played by TPB in predicting green consumption intentions. The study therefore hypothesizes that:

H4: Consumers' attitudes are positively associated with their intentions to consume green products.

H5: Consumers' subjective norms are positively associated with their intentions to consume green products.

H6: Consumers' perceived behavioral control is positively associated with their intentions to consume green products.

\subsubsection{Consumer Innovativeness}

Though consumers have ethical intentions, prior studies have indicated that greenly minded consumers seldom buy green products (Yuan, 2016). This gap as identified by Carrington et al. (2010) is important but barely given adequate attention. This study will seek to fill this gap by introducing a consumer innovativeness construct to explain that the decision to consume is also dependent on the type of a consumer. Thøgersen et al. (2010) termed consumer innovativeness as a critical determining factor of initial stages of adoption of innovative pro environmental practices. Green purchase behaviors are termed as innovative and new ideas and the innovativeness likelihood of a consumer would influence him/her to engage in green practices adoption. Therefore, consumer innovativeness would potentially influence a consumer's green products and service purchase intention.

Consumer innovativeness has been described as a driver of innovative behavior and is key in adoption and diffusion of new products and services (Im et al., 2003; Roehrich, 2004). Innovative consumers are more open to change and are more inclined to values enhancing creativity, stimulation and curiosity. Prior literature has established that young adult consumers demonstrate considerable higher levels of consumer innovativeness than consumers in other demographics brackets. These findings are congruent with the choice of students at an institution of higher learning as the main respondents although as argued out by other scholars 
later, age is not the only determining factor for consumer innovativeness. Young adults are however considered a particularly paramount segment because they are in the process of developing their consumption identities as well as engaging in social learning (Carpenter et al., 2012). They also play a major role in determining the wholesome household's consumption pattern (Grant \& Waite, 2003).

This study expands the study by Englis and Phillips (2013) by defining an innovative consumer as a consumer who yearns to seek out the novel and different, is not risk averse, and is more willing to share new ideas and discoveries with others. Consumers with high innovativeness tend to appreciate new products more, are enticed to use the new products and are motivated to try new ways to solve old problems (Jansson, 2011). In addition, empirical research has confirmed that consumer innovativeness influences early stages of the innovation decision process such as awareness (Yuan, 2016). Therefore, in line with the literature reviewed, this study hypothesizes that:

H7: Consumer innovativeness positively moderates the relationship between green products' utilitarian value and attitude; thus, the relationship is stronger when consumer innovativeness is high compared to when it is low.

H8: Consumer innovativeness positively moderates the relationship between environmental value and attitude; thus, the relationship is stronger when consumer innovativeness is high compared to when it is low.

H9: Consumer innovativeness positively moderates the relationship between hedonic value and attitude; thus, the relationship is stronger when customer innovativeness is high compared to when it is low.

\section{Methodology}

\subsection{Measurements and Instrument Development}

A questionnaire was developed based on multi-item measures that were adapted from previous studies and personally administered. An opening remark was included which defined green products as 'products that are environmentally friendly and eco-friendly. They enhance a better quality of life, minimize natural resources and toxic materials' use, are remanufactured products, are manufactured in environmentally friendly workplaces and minimize emissions of pollutants and waste over their lifecycle.' The questionnaire comprised of three sections with section one consisting of the respondents demographic profile. Section II consisted of the green value dimensions whereby the respondents stated the importance they attach to these values in relation to the TPB factors. Section III included the TPB factors of attitude, subjective norm and perceived behavioral control, and the respondents were asked to indicate how the three factors influence their decision to consume green products. The questionnaire used a seven-point Likert scale format which ranged from 1- Very small extent, 2- Small extent, 3- Moderately Small extent, 4- Neutral 5- Moderately large extent, 6- Large extent and 7- Very Large extent. In order to ensure content validity, a professor and a senior doctoral student in marketing reviewed the questionnaire. A pilot test was conducted by randomly selecting 40 students who were excluded from the main research in order to avoid sensitization effect. The consistency test on all constructs established Cronbach's $\alpha$ scores that ranged between 0.83 and 0.94 . This was above the threshold value of $(\alpha \geq 0.7)$. 


\subsection{Procedures}

Upon adjustment of the questionnaire based on the feedback from the piloted respondents, the questionnaire was distributed to the target population at a renowned university in China. The University was selected due to its large population of both Chinese and international students. Convenience sampling technique was applied. The technique was chosen since extant literature has found it fit for data collection most especially when the nature of research is exploratory (Roman, 2007; Seckler et al., 2015). This was achieved through administration of online questionnaires via social networking sites and emails and also hand deliveries at relaxation places such as cafeterias and the school parks following the approach by Filieri et al. (2018). Arrangements were made on possible dates of collecting the hand filled questionnaires from the respondents. A reminder through personalized emails and messages was sent to the online respondents three weeks after the initial mailing. Completion of the questionnaire was estimated to take between ten and fifteen minutes. Out of the target population of 650 respondents, 516 filled the questionnaire, but upon scrutiny, 90 questionnaires were partially filled or had extreme values and therefore were discarded. The researchers therefore ended up with 426 valid questionnaires for data analysis.

\section{Result}

\subsection{Respondents' Profile}

The study sought to establish the respondents' gender, age, level of education, monthly income or allowance and nationality. Table 1 summarizes the demographics. Both male and female participated in the survey in almost equal measures with $50.2 \%$ female and $49.8 \%$ male. The age bracket with highest respondents was between 26 and 30 years at 26.4\%. This age bracket consist of the millennia's who are deemed to be the greenest and most environmentally friendly largely because of availability of information in regards to environment through media (Barber et al., 2010). Most of the respondents were students taking a masters' degree (48.8\%), while $65.3 \%$ of the respondents earned a monthly income of between 2501 and $5000 \mathrm{Rmb}$. Most of the respondents were drawn from Asia accounting to $36.9 \%$. This was credited to the fact that the research was carried out in Beijing-China.

\subsection{Measurement model}

Structural equation modelling by use of AMOS-graphics was used in data analysis. In measurement model, a two-step statistical analysis was adopted in this study following studies by Anderson and Gerbing (1988). First step analyzed reliability and validity of the measurement model while the second step carried out the path analysis of the structural model. This technique ensured reliability and validity of the measures prior to establishing their structural relationship. In order to establish the validity of latent constructs, Confirmatory factor analysis was carried out. The resultant factor loadings for all items were above the required minimum of 0.70 apart from UV5 (0.583) and PBC5 (0.652) which were removed from further analysis. Results from CFA yielded good model fitness which indicated that the goodness-of-fit indices for the measurement model were within the acceptable range $\left(\chi^{2}=601.88, \mathrm{df}=201 \chi^{2} / \mathrm{df}=2.99\right.$, $p<0.001$, Goodness of Fit Index $(G F I)=0.957$, Adjusted Goodness of Fit Index $(A G F I)=0.887, N F I$ $=0.923, C F I=0.976, R F I=0.917$, Root Mean Square Error of Approximation $(\mathrm{RMSEA})=0.04(\mathrm{Hu}$ \& Bentler, 1999). Composite Reliability scores were used to test for reliability. Table 2 shows that all the CR scores ranged between 0.79 and 0.94 thus exceeding the recommended minimum 
threshold of 0.70 (Hair et al., 2011). Convergent validity was tested through two standards (Fornell \& Larcker, 1981); first, all factor loadings should exceed the minimum value of 0.70 and Average Variance Extracted (AVE) for each construct to exceed 0.50. Factor loadings for all the constructs exceeded 0.70. AVE values also exceeded 0.50 ranging from 0.57 and 0.70 . Two tests were carried out to check for discriminant validity. First, the correlations among the constructs were expected to be below 0.85 and secondly, the $A V E$ square root was to exceed the correlations of a construct with the other latent constructs in the model (Fornell \& Larcker, 1981; Kline, 2005). Table 2 and 3 shows that the measurement model fulfilled these requirements.

Table 1. Respondents' Profile

\begin{tabular}{|c|c|c|}
\hline Demographic Information & Frequency & Percentage \\
\hline \multicolumn{3}{|l|}{ Gender } \\
\hline Male & 212 & 49.8 \\
\hline Female & 214 & 50.2 \\
\hline \multicolumn{3}{|l|}{ Marital Status } \\
\hline Single & 200 & 46.9 \\
\hline Married & 226 & 53 \\
\hline \multicolumn{3}{|l|}{ Age } \\
\hline 18- 25 & 82 & 19.2 \\
\hline $26-30$ & 112 & 26.3 \\
\hline 31- 35 & 92 & 21.6 \\
\hline $36-40$ & 83 & 19.5 \\
\hline 40 and above & 57 & 13.4 \\
\hline \multicolumn{3}{|l|}{ Education Level } \\
\hline Undergraduate & 132 & 30.9 \\
\hline Masters' & 208 & 48.8 \\
\hline Doctorate & 49 & 11.5 \\
\hline Exchange Program & 32 & 8 \\
\hline Others & 5 & 1 \\
\hline \multicolumn{3}{|l|}{ Monthly Allowance (Rmb) } \\
\hline 1 to 2500 & 127 & 29.8 \\
\hline $2501-5000$ & 278 & 65.3 \\
\hline 5000 and above & 21 & 4.9 \\
\hline \multicolumn{3}{|l|}{ Nationality } \\
\hline Asian & 157 & 36.9 \\
\hline European & 62 & 14.6 \\
\hline African & 101 & 23.7 \\
\hline American & 59 & 13.8 \\
\hline Others & 47 & 11 \\
\hline
\end{tabular}


Table 2. Confirmatory Factor Analysis Statistics

\begin{tabular}{|c|c|c|c|c|}
\hline Constructs & Items & Statement & References & $S F L$ \\
\hline \multirow{4}{*}{$\begin{array}{l}\text { Utilitarian } \\
\text { value (UV) } \\
\alpha=0.872 \\
C R=0.87 \\
A V E=0.60\end{array}$} & UV1 & $\begin{array}{l}\text { I buy remanufactured products such as phones } \\
\text { and home appliances because in so doing I assist } \\
\text { in saving the environment }\end{array}$ & \multirow[t]{4}{*}{$\begin{array}{l}\text { Arndt (2005), } \\
\text { Winterich et } \\
\text { al. (2019) }\end{array}$} & $0.710^{* * *}$ \\
\hline & UV2 & $\begin{array}{l}\text { I consider the possibility of recycling packaging } \\
\text { materials when making a purchase }\end{array}$ & & $0.876^{* * *}$ \\
\hline & UV3 & $\begin{array}{l}\text { I always find a way of recycling my waste for } \\
\text { example by making flowers and flower pots out of } \\
\text { plastic bottles }\end{array}$ & & $0.812^{* * *}$ \\
\hline & UV4 & $\begin{array}{l}\text { I consider the packaging strategies when making } \\
\text { purchases and if I feel the product is over- } \\
\text { packaged I seldom buy }\end{array}$ & & $0.721^{* * *}$ \\
\hline \multirow{4}{*}{$\begin{array}{l}\text { Environmental } \\
\text { value (EV) } \\
\alpha=0.863 \\
C R=0.86 \\
A V E=0.57\end{array}$} & EV1 & $\begin{array}{l}\text { I consider eco-labels in products when buying } \\
\text { electronic appliances. }\end{array}$ & \multirow{4}{*}{$\begin{array}{l}\text { Elgaaïed- } \\
\text { Gambier } \\
(2016), \\
\text { Vasiljevic- } \\
\text { Sikaleska et } \\
\text { al. (2018), } \\
\text { Poon et al. } \\
\text { (2001) }\end{array}$} & $0.802^{* * *}$ \\
\hline & EV2 & $\begin{array}{l}\text { I prefer buying eco-friendly products in order to } \\
\text { minimize pollution }\end{array}$ & & $0.832^{* * *}$ \\
\hline & EV3 & $\begin{array}{l}\text { I take the initiative to separate waste at the } \\
\text { collection points in order to enhance waste } \\
\text { management. }\end{array}$ & & $0.735^{* * *}$ \\
\hline & EV4 & $\begin{array}{l}\text { I consider buying green products because they are } \\
\text { more environmentally friendly than other } \\
\text { products. }\end{array}$ & & $0.857^{* * *}$ \\
\hline \multirow{4}{*}{$\begin{array}{l}\text { Hedonic Value } \\
\text { (HV) } \\
\alpha=0.80 \\
C R=0.80 \\
A V E=0.70\end{array}$} & HV1 & $\begin{array}{l}\text { Shopping and looking around for green products } \\
\text { is an exciting pastime for me }\end{array}$ & \multirow[t]{4}{*}{$\begin{array}{l}\text { Park (2010), } \\
\text { Kuhl (2000) }\end{array}$} & $0.789^{* * *}$ \\
\hline & HV2 & $\begin{array}{l}\text { Am interested in new green products and keep } \\
\text { researching about them. }\end{array}$ & & $0.876^{* * *}$ \\
\hline & HV3 & $\begin{array}{l}\text { When shopping for green products I look around } \\
\text { various stores for them. }\end{array}$ & & $0.833^{* * *}$ \\
\hline & HV4 & $\begin{array}{l}\text { Purchasing green products gives me personal } \\
\text { fulfillment }\end{array}$ & & $0.855^{* * *}$ \\
\hline \multirow{4}{*}{$\begin{array}{l}\text { Attitude (ATT) } \\
\alpha=0.94 \\
C R=0.95 \\
A V E=0.61\end{array}$} & ATT1 & $\begin{array}{l}\text { I like consuming green products since they are } \\
\text { environmentally friendly }\end{array}$ & \multirow{4}{*}{$\begin{array}{l}\text { Ajzen and } \\
\text { Fishbein } \\
\text { (1980), Huh } \\
\text { (2011), } \\
\text { Shaw and } \\
\text { Shiu (2002) }\end{array}$} & $0.900^{* * *}$ \\
\hline & ATT2 & $\begin{array}{l}\text { Purchasing green products makes me feel } \\
\text { environmentally responsible }\end{array}$ & & $0.935^{* * *}$ \\
\hline & ATT3 & I am interested in purchasing green products & & $0.909 * * *$ \\
\hline & ATT4 & Purchasing green products is wise & & $0.889 * * *$ \\
\hline \multirow{4}{*}{$\begin{array}{l}\text { Subjective } \\
\text { Norms (SN) } \\
\alpha=0.834 \\
C R=0.80 \\
A V E=0.59\end{array}$} & SN1 & $\begin{array}{l}\text { I buy green products because people close to me } \\
\text { believe that I should be environmentally friendly. }\end{array}$ & \multirow{4}{*}{$\begin{array}{l}\text { Pihlström } \\
\text { and Brush } \\
(2008)\end{array}$} & $0.877^{* * *}$ \\
\hline & SN2 & $\begin{array}{l}\text { I buy green products because the society believes } \\
\text { that I should be environmentally friendly. }\end{array}$ & & $0.866^{* * *}$ \\
\hline & SN3 & $\begin{array}{l}\text { When alone I rarely consider green values when } \\
\text { making a purchase but when in company of } \\
\text { friends I consider green values. }\end{array}$ & & $0.793^{* * *}$ \\
\hline & SN4 & $\begin{array}{l}\text { I buy green products because everyone else is } \\
\text { buying them. }\end{array}$ & & $0.801^{* * *}$ \\
\hline \multirow{4}{*}{$\begin{array}{l}\text { Perceived } \\
\text { Behavioral } \\
\text { Control (PCB) } \\
\alpha=0.862 \\
C R=0.87 \\
A V E=0.57\end{array}$} & PBC1 & $\begin{array}{l}\text { I consider buying green products because of their } \\
\text { ease of use. }\end{array}$ & \multirow{4}{*}{$\begin{array}{l}\text { Ajzen and } \\
\text { Fishbein } \\
\text { (1980) }\end{array}$} & $0.775^{* * *}$ \\
\hline & PBC2 & $\begin{array}{l}\text { I consider buying green products because of their } \\
\text { availability. }\end{array}$ & & $0.768^{* * *}$ \\
\hline & РBC3 & $\begin{array}{l}\text { I consider buying green products because } \\
\text { information related to them is readily available. }\end{array}$ & & $0.867^{* * *}$ \\
\hline & PBC4 & $\begin{array}{l}\text { I consider buying green products because of their } \\
\text { easy accessibility. }\end{array}$ & & $0.892^{* * *}$ \\
\hline
\end{tabular}


Table 3. Confirmatory Factor Analysis Statistics (cont'd)

\begin{tabular}{|c|c|c|c|c|}
\hline Constructs & Items & Statement & References & SFL \\
\hline \multirow{4}{*}{$\begin{array}{l}\text { Consumption } \\
\text { Intention (CI) } \\
\alpha=0.90 \\
C R=0.91 \\
A V E=0.62\end{array}$} & CI1 & I intend to buy and consume green products. & \multirow{4}{*}{$\begin{array}{l}\text { Shaw and } \\
\text { Shiu (2002), } \\
\text { Huh (2011) }\end{array}$} & $0.772^{* * *}$ \\
\hline & $\mathrm{CI} 2$ & I plan to buy and consume green products. & & $0.795^{* * *}$ \\
\hline & CI3 & $\begin{array}{l}\text { Given a choice of green products and otherwise } \\
\text { non green products, I would choose to buy and } \\
\text { consume the green products over the non-green } \\
\text { products. }\end{array}$ & & $0.856^{* * *}$ \\
\hline & CI4 & $\begin{array}{l}\text { I am ready to gear my efforts towards actions that } \\
\text { will improve the environment }\end{array}$ & & $0.746^{* * *}$ \\
\hline Consumer & CINI & Trying new things excites me. & \multirow{4}{*}{$\begin{array}{l}\text { Goldsmith } \\
\text { and Hofacker } \\
\text { (1991) }\end{array}$} & $0.823^{* * *}$ \\
\hline $\begin{array}{l}\text { Innovativeness } \\
(\mathrm{CIN})\end{array}$ & CIN2 & $\begin{array}{l}\text { I often try new ways of living in order to improve } \\
\text { over my past ways }\end{array}$ & & $0.856^{* * *}$ \\
\hline $\begin{array}{l}\alpha=0.91 \\
C R=0.90 .\end{array}$ & CIN3 & $\begin{array}{l}\text { I yearn to acquire new products as soon as they } \\
\text { enter the market }\end{array}$ & & $0.886^{* * *}$ \\
\hline$A V E=0.59$ & CIN4 & I consider myself an innovative person & & $0.766^{* * *}$ \\
\hline
\end{tabular}

Abbreviations: $\alpha=$ Cronbach's alpha, $C R=$ Composite Reliability, $A V E=$ Average Variance Extracted, $S F L=$ Standardized factor loadings $* * * \mathrm{p}<0.001$

Table 4. Discriminant validity

\begin{tabular}{lcccccccc}
\hline & UV & EV & HV & ATT & SN & PBC & CI & CIN \\
\hline Utilitarian Value (UV) & $\mathbf{0 . 7 7 5}$ & 0.521 & 0.231 & 0.040 & 0.821 & 0.180 & 0.126 & 0.154 \\
Environmental Value (EV) & & $\mathbf{0 . 7 5 5}$ & 0.573 & 0.180 & 0.157 & 0.052 & 0.192 & 0.231 \\
Hedonic value (HV) & & & $\mathbf{0 . 8 3 7}$ & 0.301 & 0.030 & 0.278 & 0.731 & 0.124 \\
Attitude (ATT) & & & & $\mathbf{0 . 7 8 1}$ & 0.311 & 0.201 & 0.153 & 0.478 \\
Subjective Norm (SN) & & & & & $\mathbf{0 . 7 6 8}$ & 0.310 & 0.242 & 0.023 \\
Perceived Behavioral Control (PBC) & & & & & & $\mathbf{0 . 7 5 4}$ & 0.321 & 0.321 \\
Consumption Intention (CI) & & & & & & & $\mathbf{0 . 7 5 9}$ & 0.232 \\
Consumer Innovativeness (CIN) & & & & & & & & $\mathbf{0 . 7 6 8}$ \\
\hline Mean & 3.54 & 3.10 & 2.94 & 3.60 & 2.73 & 3.31 & 3.22 & 3.45 \\
SD & 0.94 & 0.65 & 0.95 & 1.10 & 0.94 & 1.21 & 1.03 & 0.93 \\
VIF & 1.982 & 1.872 & 1.043 & 1.387 & 1.467 & 1.031 & 1.506 & 1.476 \\
\hline Note: The bold numbers in diagonal row are square root of AVE & & & & & &
\end{tabular}

\subsection{Common method variance}

Since the study was cross sectional with a single source of data, methodological tests were conducted in order to test the robustness of common method variance (Podsakoff et al., 2003). An exploratory factor analysis was carried out for all the items. The results indicated that for every single factor a $27.9 \%$ variance among them was accounted for. No single factor accounted for majority of variance and therefore, this suggested that common method variance was not an issue in this study.

\subsection{Hypotheses testing and results}

The hypothesized relationships were tested by Structural Equation Modeling through Amos- graphics. SEM main focus is on interrelationships among manifest and latent constructs in path analysis and also indicates an overall model fitness while measuring the direct and indirect 
effects of causal models (Ashraf et al, 2019). To test for multi-collinearity effect, SPSS was applied. Table 3 shows the results for variance inflation factor which ranged between 1.031 and 1.982. These were below the recommended cut off value of 3.0 which therefore indicated that multi-collinearity was not an issue. The empirical results of the hypothesis testing for the structural model in Figure 1 are as depicted in Table 4.

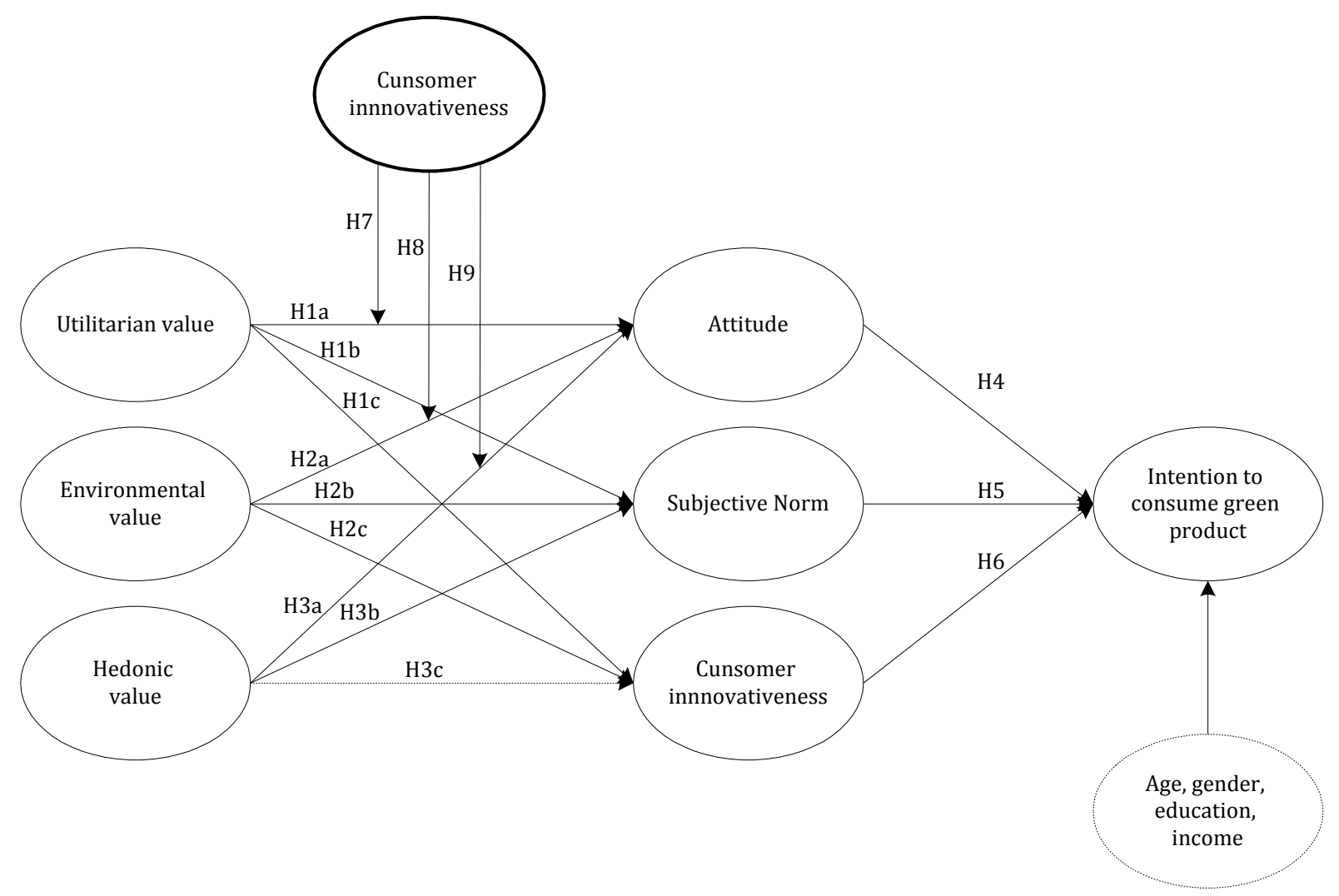

Figure 1. Research model

The results of the hypothesis testing indicate that utilitarian value had a positive effect on the TPB factors (H1a- $\beta_{\mathrm{UV} \rightarrow \mathrm{ATT}}=0.578, t=4.638, p<0.05$; $\mathrm{H} 1 \mathrm{~b}-\beta_{\mathrm{UV} \rightarrow \mathrm{SN}}=0.308, t=4.281, p<$ $\left.0.001 ; \mathrm{H} 1 \mathrm{c}-\beta_{\mathrm{UV} \rightarrow \mathrm{PBC}}=0.412, t=4.910, p<.05\right)$ thus, $\mathrm{H} 1$ was supported. $\mathrm{H} 2$ results were as follows (H2a- $\beta_{\mathrm{EV} \rightarrow \mathrm{ATT}}=0.393, t=4.015, p<0.05 ; \mathrm{H} 2 \mathrm{~b}-\beta_{\mathrm{EV} \rightarrow \mathrm{SN}}=0.252, t=4.281, p<0.05$; $\mathrm{H} 2 \mathrm{c}-$ $\left.\beta_{\mathrm{EV} \rightarrow \mathrm{PBC}}=.228, t=2.151, p<.05\right)$ thus, $\mathrm{H} 2$ was also supported. $\mathrm{H} 3$ was partially supported since hedonic value had significant positive effect on attitude and subjective norm (H3a- $\beta_{\mathrm{HV} \rightarrow \mathrm{ATT}}=$ $\left.0.520, t=5.238, p<0.05 ; \mathrm{H} 3 \mathrm{~b}-\beta_{\mathrm{EV} \rightarrow \mathrm{SN}}=0.505, t=4.868, p<0.05\right)$. The relationship between hedonic value and perceived behavioral control however, was found to be insignificant (H3c- $\beta_{\mathrm{HV}}$ $\rightarrow \mathrm{PBC}=0.280, t=1.393, p>0.05)$. Moreover, the three factors of the theory of planned behavior had significant positive relationship with consumption intention. Attitude (H4- $\beta_{\mathrm{ATT} \rightarrow \mathrm{CI}}=0.401, t$ $=4.868, p<.05)$, thus $\mathrm{H} 4$ was supported. Subjective norm ( $\left.\mathrm{H} 5-\beta_{\mathrm{SN} \rightarrow \mathrm{CI}}=0.398, t=2.321, p<.05\right)$. H5 was supported. The most important data result was that perceived behavioral control had a significant positive relationship with intention to consume (H6- $\beta_{\mathrm{PBC} \rightarrow \mathrm{CI}}=.228, t=1.393, p<.05$ ). Thus H6 was supported. 
Table 5. Results of the hypothesis

\begin{tabular}{|c|c|c|c|c|}
\hline Path & $\begin{array}{c}\text { Coefficient } \\
\text { estimate }\end{array}$ & $\begin{array}{c}\mathrm{t}- \\
\text { statistics }\end{array}$ & p-value & Relationship \\
\hline H1a. Utilitarian value $\rightarrow$ attitude & $0.578^{* *}$ & 4.638 & $<0.05$ & Supported \\
\hline H1b. Utilitarian value $\rightarrow$ subjective norm & $0.308^{* * *}$ & 4.281 & $<0.001$ & Supported \\
\hline $\begin{array}{l}\text { H1c. Utilitarian value } \rightarrow \text { perceived behavioral } \\
\text { control }\end{array}$ & $0.412^{* *}$ & 4.910 & $<0.05$ & Supported \\
\hline H2a. Environmental value $\rightarrow$ attitude & $0.393^{* *}$ & 4.015 & $<0.05$ & Supported \\
\hline H2b. Environmental value $\rightarrow$ subjective norm & $0.252^{* *}$ & 2.202 & $<0.05$ & Supported \\
\hline $\begin{array}{l}\text { H2c. Environmental value } \rightarrow \text { perceived } \\
\text { behavioral control }\end{array}$ & $0.228^{* *}$ & 2.151 & $<0.05$ & Supported \\
\hline H3a. Hedonic value $\rightarrow$ attitude & $0.520^{* *}$ & 5.238 & $<0.05$ & Supported \\
\hline H3b. Hedonic value $\rightarrow$ subjective norm & $0.505^{* *}$ & 4.868 & $<0.05$ & Supported \\
\hline $\begin{array}{l}\text { H3c. Hedonic value } \rightarrow \text { perceived behavioral } \\
\text { control }\end{array}$ & 0.280 & 1.393 & $>0.05$ & Unsupported \\
\hline H4. Attitude $\rightarrow$ Consumption intention & $0.401^{* *}$ & 4.868 & $<0.05$ & Supported \\
\hline $\begin{array}{l}\text { H5. Subjective norm } \rightarrow \text { Consumption } \\
\text { Intention }\end{array}$ & $0.398^{* *}$ & 2.321 & $<0.05$ & Supported \\
\hline $\begin{array}{l}\text { H6. Perceived behavioral control } \\
\rightarrow \text { consumption intention }\end{array}$ & $0.228^{* *}$ & 2.151 & $<0.05$ & Supported \\
\hline $\begin{array}{l}\text { H7. Utilitarian value } \times \text { consumer } \\
\text { innovativeness } \rightarrow \text { attitude }\end{array}$ & $0.119^{* *}$ & 2.457 & $<0.05$ & Supported \\
\hline $\begin{array}{l}\text { H8. Environmental value } \times \text { consumer } \\
\text { innovativeness } \rightarrow \text { attitude }\end{array}$ & $0.158^{* *}$ & 3.251 & $<0.05$ & Supported \\
\hline \multirow{2}{*}{$\begin{array}{l}\text { H9. Hedonic value } \times \text { consumer } \\
\text { innovativeness } \rightarrow \text { attitude }\end{array}$} & $0.076^{*}$ & 1.897 & $<0.01$ & Supported \\
\hline & $\begin{array}{l}\text { Structural } \\
\text { Model }\end{array}$ & & $\begin{array}{l}\text { Thresho } \\
\text { ld }\end{array}$ & \\
\hline Model fit statistics & $\begin{array}{l}\text { Chi-square = } \\
601.88 \\
\text { d.f }=201\end{array}$ & & & \\
\hline \multirow[t]{4}{*}{ Absolute fit measures } & $\begin{array}{l}\text { Normed chi- } \\
\text { square }=2.99\end{array}$ & & $1.0-3.0$ & \\
\hline & $\begin{array}{l}\text { RMSEA }= \\
0.04\end{array}$ & & $<0.08$ & \\
\hline & $\mathrm{GFI}=0.957$ & & $>0.90$ & \\
\hline & $\mathrm{AGFI}=0.887$ & & $>0.80$ & \\
\hline \multirow[t]{3}{*}{ Incremental fit measures } & $\mathrm{NFI}=0.923$ & & $>0.90$ & \\
\hline & $\mathrm{IFI}=0.976$ & & $>0.90$ & \\
\hline & $\mathrm{RFI}=0.917$ & & $>0.90$ & \\
\hline
\end{tabular}

Notes: $\mathrm{n}=426 ;{ }^{*}, * *, * * *$ indicate significance at $5 \%, 1 \%$, and $0.1 \%$ levels, respectively

\subsection{Indirect effects}

Sobel test was used to test the mediating effect of customer innovativeness on the relationship between the three PGV dimensions and attitude (Sobel, 1982). According to this test two different models that focused on the relationship of the predictor, in this case the three PGV dimensions (utilitarian, environmental and hedonic), the mediator (customer innovativeness) and the dependent variable (attitude) were run. In the first model, the path between utilitarian value $\rightarrow$ customer innovativeness, environmental value $\rightarrow$ customer innovativeness and hedonic value $\rightarrow$ customer innovativeness was modeled. The second model included the first model and attitude to test the path between (a) Utilitarian value $\times$ consumer innovativeness $\rightarrow$ attitude (b) 
Environmental value $\times$ consumer innovativeness $\rightarrow$ attitude and (c) Hedonic value $\times$ consumer innovativeness $\rightarrow$ attitude. Sobel test made an analysis of the relationship of the standard error and unstandardized beta in model 1 which represented the path from the predictor and mediator. In model 2, Sobel test made an analysis of unstandardized betas and their standard errors which were the paths from predictor to mediator, mediator to dependent variable and predictor to dependent variable (Blome et al., 2014). The test statistic for the mediating effect were H7 ( $\beta=0.119, t=1.393, p<.05)$, H8 $(\beta=0.158, t=3.251, p<.05)$ and $\mathrm{H} 9(\beta=0.076, t=$ $1.897, p<.05)$. This implies that customer innovativeness significantly mediates the relationship between the three PGV dimensions and attitude. H7, H8 and H9 were therefore supported.

\subsection{Discussion}

This study provides an advanced understanding of consumers' complex decision making process of green buying behavior while guided by TPB factors. TPB provides a model that allows prediction of intention to perform a behavior while guided by an individual's attitude, SN and PBC (Ajzen \& Fishbein, 1980). Various scholars have regarded TPB as a robust tool in evaluating consumers' decision making process (Southey, 2011). Most researchers agree that in pro environmental behaviors, personal values involving TPB factors account to the primary factors in decision making by consumers (Ashraf et al., 2018). Literature on green consumption examining the knowledge of environmental issues by Chinese consumers and how it influences their green consumption behavior is scarce (Yuan, 2016). China being the research context of this study presents one of the most significant contributions to the available literature. Previous literature in Chinese context has concentrated on cultural values of Chinese, study on demographics and ecological knowledge (Chan, 2001; Chan \& Lau, 2000; Zhao, Gao, Wu, Wang, \& Zhu, 2013). There is however a considerable lack of literature in relation to consumers' perception of green products and the decision making process in relation to the attributes of green products in China. Guided by this knowledge, this study develops a model of consumers' consumption intention towards green products while particularly guided by three perceived green value dimensions (utilitarian, environmental and hedonic value). This study obtained a number of findings as highlighted below which offer significant value both theoretically and practically to policy makers and marketers.

First, all the three PGV dimensions have significant positive influence on TPB factors of attitude and subjective norms apart from an insignificant influence between hedonic value and perceived behavioral control. This finding is in tandem with classical approaches that conclude that there exists a relationship between self-interested and pro-social behaviors of consumers (Miller et al., 2015). The research proposed a conceptual framework aimed at understanding a green consumer from a multi-value perspective. This corroborates with Chua et al. (2010) findings in a study of hybrid cars which stated that hybrid car consumers not only evaluated automobiles based on their functionality but also while considering their overall experiences. To this effect therefore, utilitarian and environmental values had significant relationship with the three TPB factors while H3a and 3b were also supported. Values as noted by Kahle \& Kennedy (1988) form one of the basic abstract methods of knowledge of an individual hence, correlating a specific product, service, works or idea to value leads to an increase in the ease of storing in the memory or recalling a specific item. Having a consideration to utilitarian and hedonic values affirms results by (Jung et al., 2016) that established that the two dimensions offer benefits to green conscious consumers and are not willing to give them up while purchasing ethical 
products. While comparing the three PGV dimension to TPB factors, utilitarian value has the strongest effect to attitude $\left(\beta=0.578^{* *}\right)$ which demonstrates that consumers in Chinese context have greater concern to remanufacturing, recycling, repackaging values. This supports findings by Yuan (2016) which established that Chinese consumers considered functional and symbolic values as the most important while ecological value was ranked fourth after epistemic value in predicting green consumption behavior (Koller et al., 2011).

Secondly, our findings established that the three TPB factors had positive relationship with consumers' intention to consume green products. Attitude had the highest impact on intention to consume $\left(\beta=0.401^{* *}\right)$. This is in tandem with various studies that have confirmed that attitude is the strongest predictor of intention in the social context (Ajzen, 1991; Olsen, 2004; Verbeke \& Vackier, 2005). The findings also corroborate with findings by Siddique (2012) which established attitude as the strongest predictor of consumption of dry fish intention in Bangladesh. It is however noted that $\mathrm{SN} \beta$ estimate value $(\beta=0.398)$ closely follows that of attitude. This can be attributed to the knowledge that Chinese consumers intended behaviors are greatly influenced by social pressures. Influence from peers, family and friends who expect Chinese consumers to behave in an eco-friendly manner greatly affect their intention to consume green products.

Lastly, the results established that consumer innovativeness strongly moderated the relationship between the three PGV dimensions and attitude. The concept of consumer innovativeness in this case sought to establish the consumers' attraction to new ideas. Questions on a seven point Likert scale were asked aimed at gauging how consumers ranked dimensions such as 'trying out new products', 'trying out new ways' and 'eagerness to acquire new products.' H7, H8 and H9 were all supported. These findings are similar to results by (Thøgersen et al., 2010) and Englis and Phillips (2013) who concluded that innovativeness as a predictor was significantly positive to pro-environmental behavior. Consumer innovativeness, a term which is derived from the Theory of Diffusions of Innovations depicts the possibility of adoption of a novel product or lifestyle by an individual (Rogers, 2003). The results also corroborated with findings by Jansson (2011) who suggested that there existed behavioral differences between individuals with high and low innovativeness. Thus, for consumers with high innovativeness, the addition of PGV dimensions to the green products would lead to an increase in consumption intention than for consumers with low innovativeness.

\section{Conclusion}

\subsection{Conclusion and contributions}

This study contributes to the current body of knowledge in the green consumption and consumer behavior. With the call for a paradigm shift from market focus to consumer focus, this study extends the current knowledge by applying the Theory of Planned Behavior and attempts to explain the consumption intention of individual consumers in relation to green products and services Chua et al. (2010). The most prominent contribution of the study is on the research context which is China. Prior studies have largely concentrated on the Western cultures (Eckhardt \& Bardhi, 2016). As noted by Yuan (2016) green consumption research in Chinese context is limited. Available findings have conceptualized Chinese green consumption in three areas of cultural values, demographics and ecological factors (Chan, 2001; Chan \& Lau, 2000; Zhao et al., 2013). There however lacks extant knowledge on how Chinese consumers perceive 
green products and how this influence their decision making process. This research therefore adds theoretical value through utilization of TPB in explaining the decision making process.

At the firm level, understanding the consumers' perception towards green products and services and most especially the barriers to consumers' adoption is of paramount importance to any firm contemplating launching eco-friendly products. This research presents perceived green value as a multidimensional construct; this presents a platform for managers in addressing each dimension differently according to its level of benefit to consumers and in promotion purposes. Highlighting the three PGV dimensions of green products allows managers to strategize their marketing skills through evaluation and improvement of green products, therefore designing measures aimed at addressing each product based on its fundamental personal values. Firms may also increase sales volumes by segmenting their markets into age, gender and income levels since these profiles have proven to have positive influence to green consumption intention.

Utilitarian and environmental values both have significant influence on consumers' intention to consume green products. This therefore calls for manufacturing companies to enhance their products offerings. Consumers who are environmental conscious will most likely engage in pro environmental behaviors by purchasing green apparel. Prior studies have indicated that individuals generally remember experiences and information which go hand in hand with their values (Ballantine et al., 2010). To achieve this, the study suggests provision of information on the values offered by the products on offer for sale by the marketing managers. The marketers could design promotion sessions using different media such as online, televisions among others outlining the ecofriendly values to prospective customers. Having a public relations campaign is also suggested in order to reach a wide range of consumers. In addition, as environment conservation is a collective responsibility for all individuals, policy makers such as government agencies would utilize these research findings in formulation of policies aimed at preserving the environment.

\subsection{Limitations and future research directions}

We acknowledge that the study has some limitations that may affect its generalizability ability. First, the study relied on cross-sectional data which was collected at one point of time with each respondent filling the whole questionnaire. Future studies might utilize longitudinal or experimental approaches to examine the role of PGV dimensions and their influence on intention to consume green products while applying TPB factors. Future studies could also incorporate other dimensions of PGV such as epistemic, symbolic and collaborative consumption in modeling green consumption intention. The research however appreciates the fact that, though the context was China, data was collected from individuals from all over the world such as from America, Africa and Europe. This provides for diverse cultural set ups and contexts. Extant research has shown that individual differences such as age, gender, education level and income levels affect the perception and decision to consume green products by consumers (Boztepe, 2012; Vasiljevic-Sikaleska et al., 2018). Lastly, future research could evaluate the impact of green literacy on consumption intention.

\section{References}

Ajzen, I. (1991). The theory of planned behavior. Orgnizational Behavior and Human Decision Processes, 50, 179-211. http://doi.org/10.1016/0749-5978(91)90020-T 
Ajzen, I., \& Fishbein, M. (1980). Understanding Attitudes and Predicting Social Behavior. New Jersey: Prentice Hall, Englewood Cliffs.

Anderson, J. C., \& Gerbing, D. W. (1988). Structural Equation Modeling in Practice: A Review and Recommended Two-Step Approach. Psychological Bulletin, 103(3), 411-423.

Arndt, M. (2005). Cat sink its claws into services. Retrieved from http://www.businessweek.com/magazine/content/05_49/b3962096.html

Ashraf, M. S., Ashraf, R. U., Kim, W. G., \& Ahmad, W. (2018). Modeling tourists' visiting intentions toward ecofriendly destinations: Implications for sustainable tourism operators. Business Strategy and the Environment, 29(1), 54-71. http://doi.org/10.1002/bse.2350

Ballantine, P. W., Jack, R., Parsons, A. G., Ballantine, P. W., \& Jack, R. (2010). Atmospheric cues and their effect on the hedonic retail experience. International Journal of Retail \& Distribution Management, 38(8), 641-653. http://doi.org/10.1108/09590551011057453

Bamberg, S. (2003). How does environmental concern influence specific environmentally related behaviors? A new answer to an old question. Journal of Environmental Psychology, 23, 21-32. http://doi.org/10.1016/S0272-4944(02)00078-6

Barber, N., Taylor, D. C., \& Deale, C. S. (2010). Wine tourism, environmental concerns, and purchase intention. Journal of Travel \& Tourism Marketing, 27(2), 146-165. http://doi.org/10.1080/10548400903579746

Belk, R. (2014). Sharing Versus Pseudo-Sharing in Web 2 . 0. Anthropologist, 18(1), 7-23. http://doi.org/10.1080/09720073.2014.11891518

Benedek, A., Takács-györgy, K., \& Konsumentów, Ś. (2013). A study of the factors influencing the environmental consciousness of consumers. Annals of the Polish Association of Agricultural and Agribusiness Economists, 15(5), 15-19.

Blome, C., Hollos, D., \& Paulraj, A. (2014). Green procurement and green supplier development: antecedents and effects on supplier performance. International Journal of Production Research, 52(1), 32-49. http://doi.org/10.1080/00207543.2013.825748

Boztepe, A. (2012). Green Marketing and Its Impact on Consumer Buying Behavior. European Journal F Economics and Politic Studies, 5(1), 5-21.

Buchholz, R. A. (1993). Principles of Environmental Management. New Jersey: Englewood Cliffs, PrenticeHaU.

Carpenter, J., Moore, M., Doherty, A. M., \& Alexander, N. (2012). Acculturation to the global consumer culture: a generational cohort comparison. Journal of Strategic Marketing, 20(5), 411-423. http://doi.org/10.1080/0965254X.2012.671340

Carrington, M. J., Neville, B. A., \& Whitwell, G. J. (2010). Why Ethical Consumers Don 't Walk Their Talk: Towards a Framework for Understanding the Gap Between the Ethical Purchase Intentions and Actual Why Ethical Consumers Don ' $t$ Walk Their Talk: Towards a Framework for Understanding the Gap Between the Ethi. Journal of Business Ethics, 97, 139-158. http://doi.org/10.1007/s10551010-0501-6

Chan, R. Y. K. (2001). Determinants of Chinese Consumers' Green Purchase Behavior. Psychology \& Marketing, 18(4), 389-413.

Chan, R. Y. K., \& Lau, L. B. Y. (2000). Antecedents of Green Purchases: A Survey in China. Journal of Consumer Marketing, 17(4), 338-357. http://doi.org/10.1108/07363760010335358 
Chandon, P., Wansink, B., \& Laurent, G. (2000). A Benefit Congruency Framework of Sales Promotion Effectiveness. Journal of Marketing, 64, 65-81. http://doi.org/10.1509/jmkg.64.4.65.18071

Chua, W., Lee, A., \& Sadeque, S. (2010). Why do people buy hybrid cars? In Proceedings of Social Marketing Forum, University of Western Australia, Western Australia, Edith Cowan University, Churchlands, W.A. (pp. 1-13). Retrieved from http://hdl.handle.net/10536/DRO/DU:30036231

Du, Y., Wang, X., Brombal, D., Moriggi, A., Sharpley, A., \& Pang, S. (2018). Changes in Environmental Awareness and Its Connection to Local Environmental Management in Water Conservation Zones: The Case of Beijing, China. Sustainability, 10, 2087. http://doi.org/10.3390/su10062087

Eckhardt, G. M., \& Bardhi, F. (2016). The relationship between access practices and economic systems. Journal of the Association for Consumer Research, 1(2), 210-225. http://doi.org/10.1086/684684

Elgaaïed-Gambier, L. (2016). Who Buys Overpackaged Grocery Products and Why? Understanding Consumers' Reactions to Overpackaging in the Food Sector. Journal of Business Ethics, 135, 683-698.

Elkins, A., \& Callaghan, D. (1978). A Managerial Odyssey: Problems in Business and its Environment, 2nd Ed. Reading: Addison-Wesley.

Englis, B., \& Phillips, D. (2013). Does innovativeness drive environmentally conscious consumer behavior? Psychology and Marketing, 30(2), 160-172. http://doi.org/10.1002/mar.20595

Erridge, A., \& Hennigan, S. (2012). Sustainable procurement in health and social care in Northern Ireland. Public Money and Management, 32(5), 363-370. http://doi.org/10.1080/09540962.2012.703422

Eurostat. (2009). Consumers in Europe, 2009 Edition.

Filieri, R., McLeay, F., Tsui, B., \& Lin, Z. (2018). Consumer perceptions of information helpfulness and determinants of purchase intention in online consumer reviews of services. Information \& Management, 55(8), 956-970. http://doi.org/10.1016/j.im.2018.04.010

Fishbein, M., \& Ajzen, I. (1975). Belief, attitude, intention, and behavior: An introduction to theory and research. Reading: MA: Addison-Wesley.

Fornell, C., \& Larcker, D. F. (1981). Evaluating Structural Equation Models with Unobservable Variables and Measurement Error. Journal of Marketing Research, 18(1), 39-50.

Goldsmith, R. E., \& Hofacker, C. F. (1991). Measuring Consumer Innovativeness. Journal of the Academy of Marketing Science, 19(3), 209-221. http://doi.org/10.1177/009207039101900306

Grant, I. C., \& Waite, K. (2003). "Following the yellow brick road" - young adults' experiences of the information super-highway. Qualitative Market Research, 6(1), 48-57. http://doi.org/10.1108/13522750310457375

Hair, J. F., Ringle, C. M., \& Sarstedt, M. (2011). PLS-SEM: Indeed a Silver Bullet. JOurnal of Marketing Theory and Practice, 19(2), 139-152. http://doi.org/10.2753/MTP1069-6679190202

Hartmann, P., \& Apaolaza-Ibáñez, V. (2012). Consumer attitude and purchase intention toward green energy brands: The roles of psychological benefits and environmental concern. Journal of Business Research, 65(9), 1254-1263. http://doi.org/10.1016/j.jbusres.2011.11.001

Head, J. (1996). China: Environmental Legislation: Report on Recent Development. East Asian Executive Reports, 15th January.

Household appliances in China 2015. (2015). Retrieved September 20, 2009, from www.marketline.comhttps://store.marketline.com/search/?s 
Hsu, H., \& Burns, L. D. (2002). Clothing Evaluative Criteria : A Cross-National Comparison of Taiwanese and United States Consumers. Clothing and Textiles Research Journal, 20(4), 246-252. http://doi.org/10.1177/0887302X0202000408

Hu, L., \& Bentler, P. M. (1999). Cutoff criteria for fit indexes in covariance structure analysis: Conventional criteria versus new alternatives. Structural Equation Modeling: A Multidisciplinary Journal, 6(1), 1-55. http://doi.org/10.1080/10705519909540118

Huh, E. J. (2011). Analysis of attitude and purchase intention regarding. Ethical Korean Journal of Consumer Studies, 22(1), 89-111.

Im, S., Bayus, B. L., \& Mason, C. H. (2003). Article Menu Access Options Download PDF [PDF] Article Metrics Cite Share Related Articles An Empirical Study of Innate Consumer Innovativeness, Personal Characteristics, and New-Product Adoption Behavior. Journal of the Academy of Marketing Science, 31(1), 61-73. http://doi.org/10.1177/0092070302238602

Jaffee, D., \& Howard, P. H. (2010). Corporate cooptation of organic and fair trade standards. Agriculture and Human Values, 27, 387-399. http://doi.org/10.1007/s10460-009-9231-8

Jansson, J. (2011). Consumer Eco-Innovation Adoption: Assessing Attitudinal Factors and Perceived Product Characteristics, 210(July 2010), 192-210.

Jørgensen, R. B., \& Moen, Ø. (2015). Eco labelling from the consumer perspective: A case study of indoor paint products. Journal of Research for Consumer, 27, 1-25.

Jung, H. J., Kim, H., \& Oh, K. W. (2016). Green Leather for Ethical Consumers in China and Korea: Facilitating Ethical Consumption with Value-Belief-Attitude Logic. Journal of Business Ethics Volume, 135, 483-502. http://doi.org/10.1007/s10551-014-2475-2

Kahle, L. R., \& Kennedy, P. (1988). Using the list of values (LOV) to understand consumers. Journal of Services Marketing, 4(2), 49-56. http://doi.org/10.1108/eb024742

Kang, J., \& Park-poaps, H. (2010). Hedonic and utilitarian shopping motivations of fashion leadership. Journal of Fashion Marketing and Management, 14(2), 312-328. http://doi.org/10.1108/13612021011046138

Kazakeviciute, A., \& Banyte, J. (2012). The relationship of consumers perceived hedonic value and behavior. Engineering Economics, 23(5), 532-540. http://doi.org/10.5755/j01.ee.23.5.1975

Kleanthous, A., \& Peck, J. (2013). Let them eat cake. Satisfyig the new consumer appetite for responsible brands. $\quad$ Godalming. Retrieved from http://assets.wwf.org.uk/downloads/let_them_eat_cake_abridged.pdf

Kline, R. (2005). PsycNET record display-PsycNET.

Koh, A.-R., \& Noh, J.-Y. (2009). Ethical Fashion Consumer Behavior in Korea - Factors Influencing Ethical Fashion Consumption. Journal of the Korean Society of Clothing and Textiles, 33(12), 1956-1964.

Koller, M., Floh, A., \& Zauner, A. (2011). Further Insights into Perceived Value and Consumer Loyalty: A “Green” Perspective. Psychological \& Marketing, 28(12), 1154-1176. http://doi.org/10.1002/mar

Kuhl, J. (2000). A functional-design approach to motivation and selfregulation. In M. Boekaerts, P. R. Pintrich, \& M. Zeidner (Eds.), Handbook of Self-Regulation (pp. 111-163). Academic Press: Academic Press.

Liu, X., Wang, C., Shishime, T., \& Fujitsuka, T. (2012). Sustainable consumption: Green purchasing behaviors of urban residents in China. Sustainable Development, 20(4), 293-308. http://doi.org/10.1002/sd.484 
Luchs, M. G., Brower, J., \& Chitturi, R. (2012). Product Choice and the Importance of Aesthetic Design Given the Emotion-laden Trade-off between Sustainability and Functional Performance. Journal of Production Innovation Management, 29(6), 903-916. http://doi.org/10.1111/j.15405885.2012.00970.x

Luchs, M. G., \& Kumar, M. (2017). “'Yes, but this Other One Looks Better/Works Better"': How do Consumers Respond to Trade-offs Between Sustainability and Other Valued Attributes? Journal of Business Ethics, 140, 567-584. http://doi.org/10.1007/s10551-015-2695-0

Mei, O. J., Ling, K. C., \& Hooi, K. K. (2012). The Antecedents of Green Purchase Intention among Malaysian Consumers. In 2012 International Conference on Economics, Business Innovation IPECR vol 38 (Vol. 38, pp. 39-43). Singapore: IACSIT Press.

Melissen, F., \& Reinders, H. (2012). A reflection on the Dutch Sustainable Public Procurement Programme. Journal of Integrative Environmental Sciences, $9(1), \quad 27-36$. http://doi.org/10.1080/1943815X.2012.658815

Miller, D., Merrilees, B., \& Coghlan, A. (2015). Sustainable urban tourism: understanding and developing visitor pro-environmental behaviours. Journal of Sustainable Tourism, 23, 26-46. http://doi.org/10.1080/09669582.2014.912219

Monnot, E., \& Reniou, F. (2012). Les suremballages: des emballages superflus pour les consommateurs? Décisions Marketing, Association Française Du Marketing, 65, 31-42.

Mustak, M. (2014). Value for business customers: Conceptualization, process, and evaluation. In 13th International Research Conference in Service Management. França.

Nielsen. (2014). Doing well by doing good. Increasingly, consumers care about Corporate Social Responsibility, but does concern convert to consumption? Retrieved from https://www.nielsen.com/ssa/en/insights/report/2014/doing-well-by-doing-good/

Oh, J., \& Yoon, S. (2014). Theory based approach to factors affecting ethical consumption. International Journal of Customer Sctudies, 38(3), 278-288. http://doi.org/10.1111/ijcs.12092

Okada, E. M. (2005). Justification Effects on Consumer Choice of Hedonic and Utilitarian Goods. Journal of Marketing Research, 42(1), 43-53. http://doi.org/10.1509/jmkr.42.1.43.56889

Olsen, S. O. (2004). Antecedents of seafood consumption behaviour: An overview. Journal of Aquatic Food Product Technology, 13(3), 79-91. http://doi.org/10.1300/J030v13n03_08

Papaoikonomou, E., Ryan, G., \& Valverde, M. (2011). Mapping Ethical Consumer Behavior : Integrating the Empirical Research and Identifying Future Directions Mapping Ethical Consumer Behavior: Integrating the Empirical Research and Identifying Future Directions. Ethic and Behavior, 21(3), 197-221. http://doi.org/10.1080/10508422.2011.570165

Papista, E., \& Krystallis, A. (2013). Investigating the Types of Value and Cost of Green Brands: Proposition of a Conceptual Framework. Journal of Business Ethics, 115(1), 75-92. http://doi.org/10.1007/s

Park, H. R. (2010). Applying anticipated affection to predict internet purchase behavior. Korean Journal of Psychology: Consumer Advertising, 11, 661-686.

Pawlak, R., \& Malinauskas, B. (2008). The use of the theory of planned behaviour to assess predictors of intention to eat fruits among 9th-grade students attending two public high schools in Eastern. Family and Consumer Sciences Research Journal, 37(1), 16-26.

Pihlström, M., \& Brush, G. J. (2008). Comparing the perceived value of information and enterteinment mobile services. Psychology and Marketing, 25(8), 732-755. http://doi.org/10.1002/mar.20236 
Podsakoff, P. M., Mackenzie, S. B., Lee, J., \& Podsakoff, N. P. (2003). Common Method Biases in Behavioral Research: A Critical Review of the Literature and Recommended Remedies. Journal of Applied Psychology, 88(5), 879-903. http://doi.org/10.1037/0021-9010.88.5.879

Poon, C. S., Yu, A. T. W., \& Ng, L. H. (2001). On-site sorting of construction and demolition waste in Hong Kong. Resources Conservation and Recycling, 32, 157-172. http://doi.org/10.1016/S0921$3449(01) 00052-0$

Prothero, A., Dobscha, S., Freund, J., Kilbourne, W. E., Luchs, M. G., Ozanne, L. K., \& Thøgersen, J. (2011). Sustainable Consumption: Opportunities for Consumer Research and Public Policy. American Marketing Association, 30(1), 31-38. http://doi.org/10.2307/23209250

Roehrich, G. (2004). Consumer innovativeness Concepts and measurements. Journal of Business Research, 57, 671-677. http://doi.org/10.1016/S0148-2963(02)00311-9

Rogers, E. R. (2003). Diffusion of Innovation. 5th ed. New York: Free Press.

Roman, S. (2007). The Ethics of Online Retailing: A Scale Development and Validation from the Consumers' Perspective. Journal of Business Ethics, 72, 131-148. http://doi.org/10.1007/s10551-006-9161-y

Roos, D., \& Hahn, R. (2019). Understanding Collaborative Consumption: An Extension of the Theory of Planned Behavior with Value-Based Personal Norms. Journal of Business Ethics, 158, 679-697. http://doi.org/10.1007/s10551-017-3675-3

Sandu, R. M. (2014). Green: Marketing, products and consumers. SEA-practical Application of Science, 2(5), 555-561.

Schepers, J., \& Wetzels, M. (2007). A meta-analysis of the technology acceptance model : Investigating subjective norm and moderation effects. Information \& Management, 44, 90-103. http://doi.org/10.1016/j.im.2006.10.007

Schwepker, C. H., \& Cornwell, T. B. (1991). An Examination of Ecologically Concerned Consumers and Their Intention to Purchase Ecologically Packaged Products. Journal of Public Policy \& Marketing, 10(2), 77-101. http://doi.org/10.1177/074391569101000205

Seckler, M., Heinz, S., Forde, S., Tuch, A. N., \& Opwis, K. (2015). Trust and distrust on the web: User experiences and website characteristics. Computers in Human Behavior, 45, 39-50. http://doi.org/10.1016/j.chb.2014.11.064

Sejwacz, D., Ajzen, I., \& Fishbein, M. (1980). Predicting and understanding weight loss: Intentions, behaviors, and outcomes. Understanding attitudes and predicting social behavior. New Jersey: Prentice-Hall, Engelwood Cliffs.

Sengupta, M., Das, J., \& Maji, P. K. (2010). Environmental Awareness and Environment Related Behaviour of Twelfth Grade Students in Kolkata : Effects of Stream and Gender. Anwesa, 5, 1-8.

Serafimova, J. (2016). Environmental concern and sustainable consumer behaviour among Macedonian consumer. Univerza v Ljubljani.

Shaw, D., \& Shiu, E. (2002). The role of ethical obligation and self-identity in ethical consumer choice. International Journal of Consumer Studies, 26(2), 109-116. http://doi.org/10.1046/j.14706431.2002.00214.x

Sheth, J. N., Newman, B. I., \& Gross, B. L. (1991). Why We Buy What We Buy : A Theory of Consumption Values. Journal of Business Research, 22(2), 159-170. http://doi.org/10.1016/0148-2963(91)900508

Siddique, M. A. M. (2012). Explaining the Role of Perceived Risk, Knowledge, Price, and Cost in Dry Fish 
Consumption Within the Theory of Planned Behavior. Journal of Global Marketing, 25(4), 181-201.

Sobel, M. (1982). Asymptotic Confidence Intervals for Indirect Effects in Structural Equation Models. In S. Leinhardt (Ed.), Sociological Methodology (pp. 290-312). Washington: American Sociological Association.

Southey, G. (2011). The Theories of Reasoned Action and Planned Behaviour Applied to Business Decisions: A Selective Annotated Bibliography. Journal of New Business Ideas \& Trends, 9(1), 43-50. http://doi.org/10.1123/jpah.2.1.76

Thøgersen, J., Haugaard, P., \& Olesen, A. (2010). Consumer responses to ecolabels. European Journal of Marketing, 44(11), 1787-1810. http://doi.org/10.1108/03090561011079882

Umuhire, L., \& Fang, Q. (2016). Method and application of ocean environmental awareness measurement: Lessons learnt from university students of China. Marine Pollution Bulletin, 102(30), 289-294. http://doi.org/10.1016/j.marpolbul.2015.07.067

UNEP. (2017). Towards a pollution free planet. United Nations Environment Programme. Retrieved from http://www.unep.org/assembly/backgroundreport

Vasiljevic-Sikaleska, A., Trpovski, G., \& Gjozinska, B. (2018). Environmental awareness and of proenvironmental consumer behavior. Journal of Sustainable Development in Africa, 8(20), 4-17.

Verbeke, W., \& Vackier, I. (2005). Individual determinants of fish consumption: application of the theory of planned behaviour. Appetite, 44(1), 67-82. http://doi.org/10.1016/j.appet.2004.08.006

Vitell, S. J. (2003). Consumer Review, Ethics Research: Synthesis for the Future Suggestions. Journal of Business Ethics, 43(1/2), 33-47. http://doi.org/10.1023/A:1022907014295

Winterich, K. P., Nenkov, G. Y., \& Gonzales, G. E. (2019). Knowing what it makes: How product transformation salience increases recycling. Journal of Marketing, 83(4), 21-37. http://doi.org/10.1177/0022242919842167

Young, W., Hwang, K., Mcdonald, S., \& Oates, C. J. (2010). Sustainable Consumption: Green Consumer Behaviour when Purchasing Products. Sustainable Development, 18, 20-31. http://doi.org/10.1002/sd.394

Yuan, R. (2016). An empirical investigation of consumers' green purchase intentions: the roles of perceived green value and utilities of consumption. Nottingham University Business School China.

Zeithaml, V. A. (1988). Consumer Perceptions of Price, Quality, and Value: A Means-End Model and Synthesis of Evidence. Journal of Marketing, 52(2), 2-22.

Zhao, H., Gao, Q., Wu, Y., Wang, Y., \& Zhu, X. (2013). What affects green consumer behavior in China? A case study from Qingdao. Journal of Cleaner Production, 1-9. http://doi.org/10.1016/j.jclepro.2013.05.021

Zimmer, M. R., Stafford, T. F., \& Stafford, M. R. (1994). Green issues: Dimensions of environmental concern. Journal of Business Research, 30(1), 63-74. http://doi.org/10.1016/0148-2963(94)90069-8 